\title{
Lactobacillus plantarum AK-3 Performance in Reducing Saponin Trembesi Leaves
}

\author{
Ahimsa Kandi Sariri \\ Universitas Veteran Bangun Nusantara \\ Sukoharjo, Indonesia \\ Emailak sariri@ymail.com
}

\author{
Ali Mursyid WM \\ Universitas Veteran Bangun Nusantara \\ Sukoharjo, Indonesia \\ Email : alimursyid_wm@yahoo.com
}

\begin{abstract}
This objective to study the effectiveness of Lactobacillus plantarum AK-3 in reducing saponin content in trembesi leaves. Trembesi leaves in fermentation with the addition of Lactobacillus plantarum AK-3 that is isolated from cow milk waste. This research is descriptive so that the data obtained is descriptive data about the performance of Lactobacillus plantarum AK-3. The conclusion is Lactobacillus plantarum AK-3 can reduce saponin content up to $0.12 \%$ and increase the protein content of $22.70 \%$.
\end{abstract}

Keywords- fermentation, Lactobacillus plantarum AK-3, trembesi leaves

\section{INTRODUCTION}

Milk is the main product of dairy livestock which is currently widely marketed in the form of packaged milk. This pure milk packaging is usually the result of pasteurization or the result of UHT technology. Both of these post-harvest milk technologies have a limited shelf life. Pasteurized pure milk is cheaper but has a shorter shelf life than UHT milk. The limitations of storing a dairy product are due to the development of bacteria contained. In the pasteurization process it will not kill all bacteria in the milk. Bacteria in milk are lactic acid bacteria. On the other hand, lactic acid bacteria can accelerate the process of trembesi leaves fermentation. Lactic acid bacteria contained in milk there are several types including Streptococcus and Lactobacillus. Lactobacillus plantarum which is used as an agent for trembesi leaf fermentation has been shown to reduce saponins.

In the waste of stale fresh cow's milk, Lactobacillus was identified as Lactobacillus plantarum. There were two Lactobacillus plantarum found, namely Lactobacillus delbrueckii and Lactobacillus plantarum which were later named after Lactobacillus plantarum AK-1. Lactobacillus plantarum was also found in stale pasteurized milk which was later named for Lactobacillus plantarum AK-2 and Lactobacillus plantarum AK-3[1] .

There are 4 types of Lactobacillus found in milk waste, to be able to utilize the Lactobacillus bacteria it is necessary to multiply. Lactobacillus propagation was found to be used by various fillers in order to find out the filler that is most suitable for Lactobacillus found.

Trembesi leaves have high potential as animal feed but have limitations in the presence of saponin content..
Fermentation is one way to reduce saponin content in leaves of trembesi. In line with this, the results of the research that have been carried out yield that the saponin content can be reduced to $0.22 \%$ [2]. To see the effectiveness of Lactobacillus obtained, it is necessary to ferment trembesi leaves by using Lactobacillus found.

From the description above, it is necessary to conduct a study which objevtive to examine the effectiveness of Lactobacillus which is found as a starter of leaf fermentation, so that it can help solve the problem of forage availability.

\section{METHODS}

The research was conducted at the Laboratory of Biology, Chemistry and Microbiology, Faculty of Agriculture, Veteran Bangun Nusantara University, Sukoharjo. Bacterial identification was carried out at the PAU Microbiology Laboratory, Gadjah Mada University, Yogyakarta. The material used was leaves of trembesi and Lactobacillus plantarum AK-3.

\section{A. Trembesi leaves Fermentation with Lactobacillus plantarum $A K-3$}

The collected trembesi leaves plus Lactobacillus plantarum AK-3 are then put in plastic, and the plastic is given small holes then covered with duct tape. After three days of demolition, the nutrient content was measured through proximate analysis and saponin analysis.

\section{B. Experimental Design}

This study will produce descriptive data in the form of results from saponin analysis and proximate analysis.

\section{RESULT AND DISCUSSION}

Before being used as a fermentor, Lactobacillus plantarum AK-3 I bacteria were cultured. Fermentation was carried out for 3 days. After 3 days of opening the fermentation, saponin content and nutrient content were analyzed through proximate analysis. The results of the analysis are listed in. 
Table 1. Nutrient and Saponin Content

\begin{tabular}{ccccccc}
\hline Bacteria & Water & Ash & Lipid & Protein & Carbohidrat & Saponin \\
\hline Non Fermentad & 5,95 & 4,44 & 6,5 & 21,76 & 61,34 & 0,53 \\
\hline$L p$ AK-3 & 8,53 & 3,62 & 5,72 & 22,7 & 59,42 & 0,12
\end{tabular}

\section{A. Nutrient Content}

The results showed that there was an increase in water content in fermented trembesi compared to non fermentation. This can be caused because Lactobacillus activity will produce acid. Lactobacillus will produce lactic acid. With acidic conditions will inhibit the activity of microorganisms in the decomposition of carbohydrates and proteins whose by products are water vapor. Table 1 . shows that trembesi leaves fermentation carried out by Lactobacillus plantarum AK-3 shows a higher moisture content compared to unfermented ones.

Ash content is an indication of mineral content in trembesi. From Table 1 it can be seen that trembesi leaves fermentation with Lactobacillus plantarum AK-3 is more rendang compared to non fermentation.

The crude fat content of leaves of trembesi decreases after fermentation Fat in more plants which is simple fat [3]. Fats are a group of heterogeneous compounds that are related both actual and potential with fatty acids. In the body, fat functions as a source of energy that is directly and potentially efficient when stored in adipose tissue.

Decreased fat content in the presence of fermentation can be caused because the energy from the existing fat is utilized by microbes to carry out fermentation. Fat in plants is usually a simple fat. Simple fats are fatty acid esters with various alcohols. Simple fat consists of fat and wax [3].

The fermentation treatment turned out to provide a substantial increase in crude protein content in the leaves of trembesi. The addition of Lactobacillus plantarum AK-3 in fermentation is also effective in increasing the crude protein content of leaves of trembesi. This can be caused because the Lactobacillus plantarum is a lactic acid bacteria that also produces bacteriocins. Bacteriocin is a bactericidal protein compound [4].

The protein content in the feed will increase the palatability of the feed. With high palatability, it will increase livestock consumption in these feeds, which is ultimately expected to increase livestock productivity.

Carbohydrates content by fermentation decrease compared to unfermented leaves of trembesi. Carbohydrates in an ingredient consist of crude fiber and extract without nitrogen. Although not a certainty, a decrease in carbohydrates can be an indication of a decrease in crude fiber.

Carbohydrates will contribute as a source of energy in an animal feed ration. See Table 1. It can be said that by fermentation using Lactobacillus can reduce the content of crude carbohydrates but still maintain crude carbohydrates in a state of high enough. It is hoped that those derived from fermentation are crude fiber. Feed with low crude fiber will increase the digestibility value of a feed [5].

\section{B. Saponin Content}

Saponin content decreases with fermentation treatment. This is in accordance with the opinion of [6] which states that by fermentation occurs the elimination of anti-nutrition substances that are toxic, including glucoside. [3] states that saponin is a glycoside, when it is hydrolyzed it produces sugar (glycone) and sapogenin (aglycone). [3] states that the highest anti-nutrient glycosides are found in leaves.

Saponin content in the trembesi leaves which is fermented with Lactobacillus plantarum AK-3 is lower than non-fermentation. This can be caused because Lactobacillus is a lactic acid bacteria, which is a bacteria that converts lactose and other sugars into lactic acid. Lactose and other sugars belong to the class of carbohydrates. Trembesi has a high carbohydrate content so that it can more effectively streamline the work of Lactobacillus which has the ability to produce bacteriocins which function as antibiotic substances $[7]$.

\section{CONCLUSION}

The conclusion is that Lactobacillus plantarum AK-3 can reduce saponin content to $0.12 \%$ and increase protein content by $22.70 \%$.

\section{ACKNOWLEDGMENT}

The preferred spelling of the word "acknowledgment" in America is without an "e" after the "g". Avoid the stilted expression "one of us (R. B. G.) thanks ...". Instead, try "R. B. G. thanks...". Put sponsor acknowledgments in the unnumbered footnote on the first page.

\section{REFERENCES}

[1] Sariri, A.K. dan Ali M. Pemanfaatan Lactobacillus Dalam Limbah Susu Sapi Untuk Agensia Fermentasi Trembesi (Sammanea Saman) Yang Digunakan Sebagai Pakan Ternak Ruminansia. Laporan Penelitian Hibah Bersaing Tahun I. Universitas Veteran Bangun Nusantara Sukoharjo, 2014.

[2] Sariri, A.K., Ali M., AI. Niken Tari. Menurunkan Saponin dengan Fermentasi untuk Meningkatkan Kelayakan Trembesi (Albizia saman) sebagai Pakan Ternak Ruminansia. Laporan Penelitian Hibah Bersaing Tahun I. Universitas Veteran Bangun Nusantara Sukoharjo, 2012.

[3] Widodo, Wahyu. Bioteknologi Fermentasi Susu. Pusat Pengembangan Bioteknologi Universitas Muhammadiyah Malang, 2002.

[4] Afriani. Pengaruh Penggunaan Starter Bakteri Asam Laktat Lactobacillus plantarum dan Laktobacillus fermentum terhadap Total 
Bakteri Asam Laktat, Kadar Asam, dan Nilai pH Dadih Susu Sapi. Jurnal Ilmiah Ilmu-Ilmu Peternakan. Volume XIII No. 6, 2010.

[5] Tillman, Allen D., Hari H, Soedomo R, Soeharto P, P. Soekanto L. Ilmu Makanan Ternak Dasar. UGM Press. Yogyakarta. 1984.

[6] Suliantari dan W.P. Rahayu. Teknologi Fermentasi Biji-bijian dan Umbi-umbian. PAU-IPB. Bogor, 1990.

[7] Taufik, E. Dadih Susu Sapi Hasil Fermentasi berbagai Starter Bakteri Probiotik yang Disimpan pada Suhu Rendah. Media Peternakan. 27(3): 88-133, 2004. 